\title{
RESPONSABILIDADE CIVIL DECORRENTE DO DANO AMBIENTAL CAUSADO POR DISPENSAÇÃo dA ÁGUA DE LASTRO, NA COSTA BRASILEIRA
}

\section{CIVIL LIABILITY OF ENVIRONMENTAL DAMAGE CAUSED BY DISPENSING \\ OF BALLAST WATER IN BRAZILIAN COAST}

\section{Carlota Bertoli Nascimento ${ }^{1}$ \\ Elaine Hahn ${ }^{2}$}

SUMÁRIO: Introdução; 1. Água de lastro: histórico, Características, funções; 1.1. Água de lastro: características e função; 2 . Água de lastro e dano ambiental; 3. Competência e responsabilidade dos agentes públicos envolvidos; 4. A responsabilidade civil; 4.1. Dano ambiental - princípios constitucionais: precaução e prevenção; 4.2. Responsabilidade civil objetiva e subjetiva; 5 . Dispensação da água de lastro e responsabilidade civil; considerações finais; referências das fontes citadas

\section{RESUMO}

O presente artigo analisa a Responsabilidade Civil dos agentes envolvidos no dano ambiental decorrente da dispensação da água de lastro, quando realizado na costa brasileira. Para tanto, o presente trabalho, possui como objetivos detectar quem são os agentes envolvidos, as incongruências diante das definições da legislação, analisar as sanções aplicáveis e avaliar as responsabilidades e aplicabilidade da legislação em vigor. Para ao final demonstrar que está na teoria da Responsabilidade Civil, sob a vertente do risco integral a efetivação de uma sanção cível, tendo em vista que o meio ambiente marinho, nos casos de poluição por água de lastro são de difícil ou impossível regeneração.

\footnotetext{
${ }^{1}$ Advogada, Mestre em Direito pela Pontifícia Universidade Católica do Rio Grande do Sul - Bolsista da Capes; professora titular das cadeiras de Direitos Reais, Direito Societário, Direito processual do trabalho, Pratica Jurídica Trabalhista, Teoria Geral do Processo e Direito Notarial e Registral da Faculdade Cenecista de Osório, na cidade de Osório, Rio Grande do Sul, Brasil. carlotabertoli@hotmail.com

${ }^{2}$ Acadêmica do Curso de Direito da Faculdade Cenecista de Osório, na cidade de Osório, Rio Grande do Sul, Brasil. elainehahn@hotmail.com
} 
NASCIMENTO. Carlota Bertoli. HAHN, Elaine. Responsabilidade Civil decorrente do dano ambiental causado por dispensação da água de lastro, na costa brasileira. Revista Eletrônica Direito e Política, Programa de Pós-Graduação Stricto Sensu em Ciência Jurídica da UNIVALI, Itajaí, v.11, n.2, 20 quadrimestre de 2016. Disponível em: www.univali.br/direitoepolitica - ISSN 1980-7791.

PALAVRAS ChaVe: Direito Marítimo, Água de Lastro, Responsabilidade Civil.

\section{ABSTRACT}

This paper analyzes the civil liability of those involved in environmental damage howsoever arising from the dispensation of ballast water when held in the Brazilian coast. The presente work has, as objective to detect who the stakeholdes, the incongruities before the legislation settings, analyzing the penalties and evaluate the responsabilities and applicability of the legislation. To demonstrate that it is the end of the civil liability theory, under the strand of the full risk the execution of a civil sanction, considering that the marine environment, in the case of ballast water pollution are difficult or impossible regeneration.

KEYWORDS: maritime law, ballast water, civil liability.

\section{INTRODUÇÃO}

A partir do momento que o meio ambiente hígido foi elevado à categoria de direito fundamental, reconhecido como direito fundamental de terceira dimensão, o Estado passou a atuar de forma austera ao estabelecer regras a fim de atender à necessidade humana de manutenção da vida. Assim, os textos dos diplomas legais que envolvem a proteção do meio ambiente são um somatório das ações idealizadas e projetadas com uma análise mais profunda dos elementos teleológicos ${ }^{3}$ que envolvem esse Direito Humano.

Com o incremento do comércio internacional, que ocorre na sua maior parte pelo meio marítimo, a poluição telúrica ${ }^{4}$ torna-se uma das principais formas de contaminação do meio aquático, e mesmo havendo um

3 THOMĖ, Romeu. O princípio da vedação de retrocesso socioambiental. Bahia: JusPodivm, 2014, p. 122.

4 "...o que é causada por substâncias nocivas derramadas diretamente a partir da terra ou levadas pelo curso da água ou emanando de qualquer outra fonte situada em terra firme ou estruturas artificiais". SCALASSARA, Lecir Maria. Poluição marinha e proteção jurídica internacional. Curitiba: Juruá, 2008,p. 41. 
NASCIMENTO. Carlota Bertoli. HAHN, Elaine. Responsabilidade Civil decorrente do dano ambiental causado por dispensação da água de lastro, na costa brasileira. Revista Eletrônica Direito e Política, Programa de Pós-Graduação Stricto Sensu em Ciência Jurídica da UNIVALI, Itajaí, v.11, n.2, 20 quadrimestre de 2016. Disponível em: www.univali.br/direitoepolitica - ISSN 1980-7791.

direcionamento quanto à reponsabilidade civil, estabelece-se uma confusão ante a previsão legal esparsa e confusa que prevê responsabilidade dos muitos agentes envolvidos.

Nesse contexto, importante o aprofundamento sobre a problemática de se identificar quando fica definida em lei a poluição por água de lastro na costa marítima brasileira e a quem cabe a responsabilidade civil pelo dano ocasionado.

A Responsabilidade Civil, diante da dispensação da água de lastro na costa brasileira, tem por escopo imputar sanção aos atos que estejam em dissonância com a legislação e provocam dano ao meio marinho.

Desse modo a teoria a ser adotada, quando ocorre ação ou omissão diante da dispensação da água de lastro necessita de uma observação aprofundada. As considerações expostas nos tratados e convenções internacionais, relacionados com doutrina e jurisprudência sobre essa matéria são os termômetros na aplicação das sanções. ${ }^{5}$

Assim, a presente pesquisa possui como objetivo geral analisar a quem cabe a responsabilização civil na ocorrência de danos causados por dispensação de água de lastro na costa marítima brasileira, tendo em vistas as incongruências da legislação nacional sobre o tema.

Como objetivos específicos identificar quando e como ocorre a dispensação de água de lastro, detectar quem são os possíveis agentes responsáveis direta ou subsidiariamente e demonstrar, tudo segundo a legislação nacional, quais são as sanções aplicáveis a cada um dos agentes envolvidos, analisando-se a responsabilidade civil objetiva ou subjetiva dos mesmos.

5 FReITAS, Dario Almeida Passos de. Poluição Marítima. Curitiba: Juruá, 2009,p. 115. 
NASCIMENTO. Carlota Bertoli. HAHN, Elaine. Responsabilidade Civil decorrente do dano ambiental causado por dispensação da água de lastro, na costa brasileira. Revista Eletrônica Direito e Política, Programa de Pós-Graduação Stricto Sensu em Ciência Jurídica da UNIVALI, Itajaí, v.11, n.2, 20 quadrimestre de 2016. Disponível em: www.univali.br/direitoepolitica - ISSN 1980-7791.

Como hipótese, tem-se que a reparação do dano pode ser impingida de forma subjetiva apenas ao capitão do navio, o que pode tornar a mesma impossível frente à realidade econômica desse agente.

Por outro lado, é possível buscar a responsabilização de todos aqueles envolvidos na cadeia produtora do dano, já que esses fatos ambientais interferem nos direitos fundamentais da pessoa humana, que podem sofrer lesão insanável, neste sentido é importante salientar "que a dignidade, como qualidade intrínseca da pessoa humana, é irrenunciável e inalienável" ${ }^{6}$

Metodologicamente a pesquisa pode ser concebida como pesquisa teórica, com natureza prescritiva, tendo sido utilizado o método dedutivo, partindo-se da bibliografia existente sobre o tema, para propor uma forma de responsabilização efetiva pelo dano ambiental ocasionado.

Para acolher os critérios estruturais, o presente artigo encontra-se subdividido em seis seções, além da introdutória, o marco teórico que perpassa pelo conceito, características e função da água de lastro, os danos ambientais que essa pode causar, a competência e responsabilização dos agentes públicos fiscalizatórios, a definição da aplicação da teoria da responsabilidade civil objetiva ou subjetiva para o caso de ocorrência do dano ambiental, bem como a definição do agente responsável, e, por fim são descritas as considerações finais, onde se destaca a possibilidade de responsabilização não apenas do capitão do navio, como dos demais agentes envolvidos na cadeia produtora do dano.

\section{1. ÁGUA DE LASTRO: HISTÓRICO, CARACTERÍSTICAS, FUNÇõES}

A navegação, lacustre ou marítima, é substancial para desenvolvimento econômico mundial. Neste contexto destacam-se, principalmente, as

6 SARLET, Ingo Wolfgang. LEITE. George Salomão. Direitos Fundamentais e biotecnologia. São Paulo: Método, 2008, p.19. 
NASCIMENTO. Carlota Bertoli. HAHN, Elaine. Responsabilidade Civil decorrente do dano ambiental causado por dispensação da água de lastro, na costa brasileira. Revista Eletrônica Direito e Política, Programa de Pós-Graduação Stricto Sensu em Ciência Jurídica da UNIVALI, Itajaí, v.11, n.2, 20 quadrimestre de 2016. Disponível em: www.univali.br/direitoepolitica - ISSN 1980-7791.

atividades de comercialização e ou prestação de serviços realizados através das águas interiores e dos mares. As embarcações acompanharam a evolução tecnológica e o desenvolvimento empresarial que fora intensificado pela revolução industrial.

Nesta época, início do século XIX, as embarcações então movidas a vapor, passaram a operar com motor de combustão interna. A comercialização de produtos é impulsionada pelo transporte marítimo, pois a operacionalização do transporte aquático sempre foi intensa, tendo em vista a economia que se pode obter através desta forma de deslocamento. $^{7}$

Independente das mudanças mecânicas, na navegação sempre houve necessidade da utilização de material, denominado lastro, assim o equilíbrio necessário à segurança da embarcação depende deste material. ${ }^{8}$

Lastro é qualquer material que possa ser utilizado para compor a estabilidade de algum objeto. Em sentido lato sensu, pode ser representado por qualquer material que, fazendo peso no fundo do porão do navio, mantenha a estabilidade do mesmo, como a areia, pedras ou água. ${ }^{9}$

Em determinado tempo foram utilizados materiais sólidos. Atualmente na navegação utiliza-se água, que é "recolhida do mar e armazenada em tanques nos porões dos navios, com o objetivo de dar estabilidade às

7 SOUSA, Marcos Ticiano Alves de. A bioinvasão de ambientes aquáticos provocada pela água de lastro das embarcações e suas consequências jurídicas. 2014. 83f. Trabalho de Conclusão de Curso (Monografia) - Departamento de Direito, Universidade Federal do Rio Grande do Norte, Natal, 2014, p. 17.

8 SOUSA, Marcos Ticiano Alves de. A bioinvasão de ambientes aquáticos provocada pela água de lastro das embarcações e suas consequências jurídicas. p. 20.

9 GIBERTONI, Carla Adriana Comitre. Teoria e prática do direito marítimo. Rio de Janeiro: Renovar, 2014, p. 574. 
NASCIMENTO. Carlota Bertoli. HAHN, Elaine. Responsabilidade Civil decorrente do dano ambiental causado por dispensação da água de lastro, na costa brasileira. Revista Eletrônica Direito e Política, Programa de Pós-Graduação Stricto Sensu em Ciência Jurídica da UNIVALI, Itajaí, v.11, n.2, 20 quadrimestre de 2016. Disponível em: www.univali.br/direitoepolitica - ISSN 1980-7791.

embarcações quando elas estão navegando sem cargas. ${ }^{10}$. A água de lastro é crucial para a segurança e eficiência das operações de navegação atuais. ${ }^{11}$

No Brasil a legislação que gerencia o lastro, são as regras impostas através da NORMAN $20^{12}$ define água de lastro, como "a água com suas partículas suspensas levada a bordo de uma embarcação nos seus tanques de lastro, para o controle do trim, banda, calado, estabilidade ou tensões da embarcação." ${ }^{13}$ Além do controle da Resolução da Diretoria Colegiada - RDC No 72, da Agencia Nacional de Vigilância Sanitária (ANVISA). ${ }^{14}$

Embora, haja um gerenciamento na dispensação o "movimento de água de lastro proporciona o transporte diário de cerca de sete mil espécies entre as diferentes regiões do mundo" ${ }^{15}$ e seus impactos na saúde e na economia são imprevisíveis.

A transferência destas espécies decorre de atividade inerente operação marítima, não existindo meios totalmente satisfatórios de prevenção para todos os navios e inclusive a existência ou não da água de lastro pode

10 Meio Ambiente: Água de Lastro. Disponível em: <http://www.portodesantos.com.br/acoesCampanhas.php?pagina=02>. Acesso em 19 abr. 2015.

11 GIBERTONI, Carla Adriana Comitre. Teoria e prática do direito marítimo, p. 574.

12 Definida como: Normas da autoridade marítima. Diretoria de Portos Costas. Disponibilizado em:<https://www.dpc.mar.mil.br/normas/normam>. Acesso em: 02 set 2015.

13 Norma da Autoridade Marítima, editada em 2005, atualizada em 2014. Trata do gerenciamento da água de lastro das embarcações. Outorgada através de lei. Disponibilizado em: < https://www.dpc.mar.mil.br/normas/normam>. Acesso em: 13 set. 2015.

14 Resolução da Diretoria Colegiada - RDC No 72, DE 29 DE DEZEMBRO DE 2009. Dispõe sobre o Regulamento Técnico que visa à promoção da saúde nos portos de controle sanitário instalados em território nacional, e embarcações que por eles transitem. Disponível em: < http://portal.anvisa.gov.br/wps/wcm/connect/9cc3f800474576208429d43fbc4c6735/ $\mathrm{RDC}+\mathrm{N} \% \mathrm{C} 2 \% \mathrm{BAo}+72+\mathrm{DE}+29+\mathrm{DE}+\mathrm{DEZEMBRO}+\mathrm{DE}+2009 . \mathrm{pdf} ? \mathrm{MOD}=\mathrm{AJPERES}>$. Acesso em: 29 nov. 2015

${ }^{15}$ GIBERTONI, Carla Adriana Comitre. Teoria e prática do direito marítimo,p. 575. 
NASCIMENTO. Carlota Bertoli. HAHN, Elaine. Responsabilidade Civil decorrente do dano ambiental causado por dispensação da água de lastro, na costa brasileira. Revista Eletrônica Direito e Política, Programa de Pós-Graduação Stricto Sensu em Ciência Jurídica da UNIVALI, Itajaí, v.11, n.2, 20 quadrimestre de 2016. Disponível em: www.univali.br/direitoepolitica - ISSN 1980-7791.

resultar em operações com risco de segurança ao navio e a sua tripulação. ${ }^{16}$

\section{1. ÁGUA DE LASTRO: CARACTERÍSTICAS E FUNÇÃO}

A água de lastro, como regra, não é purificada. Quando dispensada, no mar, a água de lastro introduz além da água servida e do lastro, "...diversas espécies marinhas em um ecossistema diferente" ${ }^{17}$, trazendo riscos inestimáveis à população.

Assim, a preocupação torna-se constante, tendo em vista a transferência de 10 bilhões de toneladas de água de lastro por ano. ${ }^{18}$ Além da poluição está a apreensão com a transferência de organismos de "diversas espécies marinhas em um ecossistema diferente". ${ }^{19}$

A gravidade da poluição marinha através da água de lastro "foi identificada como a quarta maior ameaça aos oceanos e a biodiversidade global mundial", segundo Global Ballast Water Management Programme, coordenado pela International Martime Organization- IMO. ${ }^{20}$

O deslastre constitui uma forma de contaminação cada vez mais preocupante, pois, nos casos de derramamento de óleo podem ser tomadas medidas e realizadas ações, e o meio ambiente pode eventualmente se recuperar. No caso da introdução de espécies marinhas é, na maioria dos casos, irreversível. ${ }^{21}$

${ }^{16}$ GIBERTONI, Carla Adriana Comitre. Teoria e prática do direito marítimo, p.574 578.

17 FREITAS, Dario Almeida Passos de. Poluição Marítima, p. 32.

18 Conforme dados da International Maritime Organizattion. Disponível em: <www.imo.org>. Acesso em 19 abr. 2015.

19 FREITAS, Dario Almeida Passos de. Poluição Marítima, p. 33.

20 Conforme: International Maritime Organizattion. Building Partnerships to Assist Developing Countries to Reduce the Transfer of Harmful Aquatic Organisms in Ships' Ballast Water. The GloBallast Partnerships project 2007-2016. Disponível em: <http://globallast.imo.org/>. Acesso em: 24 mar. 2015.

${ }^{21}$ GIBERTONI, Carla Adriana Comitre. Teoria e prática do direito marítimo, p.574. 
NASCIMENTO. Carlota Bertoli. HAHN, Elaine. Responsabilidade Civil decorrente do dano ambiental causado por dispensação da água de lastro, na costa brasileira. Revista Eletrônica Direito e Política, Programa de Pós-Graduação Stricto Sensu em Ciência Jurídica da UNIVALI, Itajaí, v.11, n.2, 2o quadrimestre de 2016. Disponível em: www.univali.br/direitoepolitica - ISSN 1980-7791.

O avanço tecnológico busca aliar-se às inovações cientificas a fim de apresentar uma solução agradável tanto a operacionalização quanto as estruturas, tendo em vista a importância do lastro perante a economia mundial. ${ }^{22}$

A preocupação é permanente, por tratar-se de um direito humano, fundamentalmente reconhecido, inclusive pela Carta de Direitos Humanos $^{23}$. O objeto de tutela pertence a presente e às gerações futuras, uma vez que os danos da bioinvasão são irreversíveis, de preocupação impar a aplicação do direito. ${ }^{24}$

${ }^{22}$ THOMÈ, Romeu. O princípio da vedação de retrocesso socioambiental, p.18.

23 Artigo 12.0 1. Os Estados Partes no presente Pacto reconhecem o direito de todas as pessoas de gozar do melhor estado de saúde física e mental possível de atingir. 2. As medidas que os Estados Partes no presente Pacto tomarem com vista a assegurar 0 pleno exercício deste direito deverão compreender as medidas necessárias para assegurar: a) A diminuição da mortinatalidade e da mortalidade infantil, bem como o são desenvolvimento da criança; b) O melhoramento de todos os aspectos de higiene do meio ambiente e da higiene industrial; c) A profilaxia, tratamento e controlo das doenças epidémicas, endémicas, profissionais e outras; d) A criação de condições próprias a assegurar a todas as pessoas serviços médicos e ajuda médica em caso de doença. Carta Internacional de Direitos Humanos. Disponível em: < http://direitoshumanos.gddc.pt/pdf/Ficha_Informativa_2.pdf>. Acesso em: 15 nov. 2015. Neste sentido: "Na França da Revolução, por exemplo, os direitos fundamentais podiam ser resumidos a liberdade, igualdade e fraternidade; atualmente, porém, o conceito de direitos fundamentais alcança até mesmo questão inimaginável naquela época, como o direito ao meio ambiente ecologicamente equilibrado ( $\mathrm{CF}$, art. 225, caput). Da mesma forma, a igualdade entre os sexos é um direito fundamental no Brasil (CF, art. 50, I). CAVALCANTE FILHO, João Trindade. Teoria Geral dos Direitos Fundamentais. Disponível

em: $<$ http://www.stf.jus.br/repositorio/cms/portaltvjustica/portaltvjusticanoticia/anexo/joao _trindadade_teoria_geral_dos_direitos_fundamentais.pdf $>$. Acesso em: 25 nov. 2015.

${ }^{24}$ FABRIZ, Daury Cesar, OBREGON, Marcelo Fernando Quiroga. O Dever Fundamental De Proteção Ambiental No Mar Territorial - Doi: 10.12818/P.03042340.2014v65p17.

Disponível em:<http://www.derechoycambiosocial.com/revista041/o_dever_fundamental_de_pro tec3\%87ao_ambiental.pdf>. Acesso em: 22 nov. 2015. 
NASCIMENTO. Carlota Bertoli. HAHN, Elaine. Responsabilidade Civil decorrente do dano ambiental causado por dispensação da água de lastro, na costa brasileira. Revista Eletrônica Direito e Política, Programa de Pós-Graduação Stricto Sensu em Ciência Jurídica da UNIVALI, Itajaí, v.11, n.2, 2o quadrimestre de 2016. Disponível em: www.univali.br/direitoepolitica - ISSN 1980-7791.

\section{2. ÁGUA DE LASTRO E DANO AMBIENTAL}

Diante da preocupação com as impurezas oriunda das embarcações, "forma mais antiga de poluição do meio marinho" 25 , além dos acidentes marítimos ${ }^{26}$, iniciou uma intensiva análise das formas de poluição decorrentes desse meio a fim de diminuir os danos ocasionados pelo lastro. Uma busca incansável às soluções que possam ao menos amenizar a poluição marinha no que tange a dispensação da água de lastro.

Embora sendo o Brasil um dos maiores volumes de recursos hídricos renováveis do mundo ${ }^{27}$, a preocupação com o meio marinho verifica-se após a década de setenta ${ }^{28}$, quando instrumentos internacionais de controle e fiscalização passam a ser reconhecidos e ratificados pelo Brasil. $^{29}$

25 SCALASSARA, Lecir Maria. Poluição marinha e proteção jurídica internacional. Curitiba: Juruá, 2008, p. 43

26 A Convenção das Nações Unidas sobre o Direito do Mar, define: "Art. 221.2 Acidente marítimo como: significa um abalroamento, encalhe ou outro incidente de navegação ou acontecimento a bordo de uma embarcação ou no seu exterior, de que resultem danos materiais ou ameaça iminente de danos materiais à embarcação ou à sua carga". BRASIL. DECRETO No 1.530, DE 22 DE JUNHO DE 1995. Declara a entrada em vigor da Convenção das Nações Unidas sobre o Direito do Mar, concluída em Montego Bay, Jamaica, em 10 de dezembro de 1982. Disponível em: <https://saudeglobaldotorg1.files.wordpress.com/2015/07/cnudm.pdf>. Acesso em: 25 nov. 2015.

27 BORGHETTI, Nadia Rita Boscardin. A integração das águas: Revelando o verdadeiro Aqüífero Guarani. Disponibilidade e uso da água. Disponível em: <http://www.aintegracaodaságuas.com.br/sumario/1-disponibilidade-e-uso-daágua>. Acesso em: 18 abr. 2015.

28 FREITAS, Vladimir Passos de. A constituição Federal e a Efetividade das Normas Ambientais. 3. ed. São Paulo: RT, 2005, p.18.

${ }^{29}$ A preocupação com a poluição do meio ambiente marinho surgiu com a constatação da insustentável poluição do meio ambiente humano, que inevitavelmente abrange os mares. A qualidade do meio ambiente humano e a preocupação com a poluição teve sua primeira manifestação por parte da comunidade internacional em 1972, por ocasião da Conferência das Nações Unidas sobre Meio Ambiente Humano, realizada em Estocolmo, ao fim da qual foi apresentada uma Declaração de 27 princípios (Declaração de Estocolmo), com destaque ao Princípio 21, específico à proteção do meio ambiente, transcrito, referido e recordado em diversas convenções sobre proteção do meio ambiente, entre as quais se inclui a Declaração do Rio de 1992. MORE, Rodrigo Fernandes. A poluição do meio ambiente marinho e o princípio 
NASCIMENTO. Carlota Bertoli. HAHN, Elaine. Responsabilidade Civil decorrente do dano ambiental causado por dispensação da água de lastro, na costa brasileira. Revista Eletrônica Direito e Política, Programa de Pós-Graduação Stricto Sensu em Ciência Jurídica da UNIVALI, Itajaí, v.11, n.2, 20 quadrimestre de 2016. Disponível em: www.univali.br/direitoepolitica - ISSN 1980-7791.

O Direito do Mar, compreendido como uma partícula do Direito Internacional e englobado como um espaço de todos, traz valores normativos, consagrando a existência de um espaço transnacional, devendo ser compartilhado como a idéia de um bem difuso. ${ }^{30}$

Neste interim, é proibida a descarga da água de lastro em águas de jurisdição nacional. Embora em casos específicos seja permitida, "o responsável é obrigado a reparar os danos causados ao meio ambiente e indenizar as atividades econômicas e o patrimônio público e privado." ${ }^{31}$

A dispensação da água de lastro e consequentemente a bioinvasão de espécies são graves problemas na atualidade. Refletem significativamente na sustentabilidade da sociedade, assim, cabe ao Direito a preponderância diante da fragilidade e das situações econômicas, políticas e da imprecisão cientifica. ${ }^{32}$

\section{COMPETÊNCIA E RESPONSABILIDADE DOS AGENTES PÚBLICOS ENVOLVIDOS}

Como se pode observar, a legislação brasileira a respeito da Responsabilidade Civil sobre os danos provocados quando da realização da atividade marítima não é extensa, no entanto, determina formas de responsabilidades aos mais diversos agentes.

da precaução. Disponível em: <http://www.sedep.com.br/artigos/a-poluicao-domeio-ambiente-marinho-e-o-principio-da-precaucao/>. Acesso em: 27 nov. 2015.

30 MENEZES, Wagner. O Direito do Mar. Brasília: Funag. 2015, p. 46.

${ }^{31}$ GIBERTONI, Carla Adriana Comitre. Teoria e prática do direito marítimo, p. 579.

32 DAMACENA, Fernanda Dalla Libera; SILVA, Renato Carvalho da. Bioinvasão por água de lastro: um problema de direito e uma ameaça à sustentabilidade. Revista Eletrônica Direito e Política, Programa de Pós-Graduação Stricto Sensu em Ciência Jurídica da UNIVALI, Itajaí, v.10, n.1, edição especial de 2015. Disponível em <www.univali.br/direitoepolitica - ISSN 1980-7791>. Acesso em 08 nov. 2015. 
NASCIMENTO. Carlota Bertoli. HAHN, Elaine. Responsabilidade Civil decorrente do dano ambiental causado por dispensação da água de lastro, na costa brasileira. Revista Eletrônica Direito e Política, Programa de Pós-Graduação Stricto Sensu em Ciência Jurídica da UNIVALI, Itajaí, v.11, n.2, 2o quadrimestre de 2016. Disponível em: www.univali.br/direitoepolitica - ISSN 1980-7791.

A responsabilidade quanto ao gerenciamento, controle, fiscalização, da água de lastro esta definida na Lei $9.666 / 00^{33}$ a qual disciplina o cumprimento das atividades e as coloca a cargo da "autoridade marítima, por intermédio de suas organizações competentes" ${ }^{134}$, especificando suas atribuições.

A lei em comento dispõe da prevenção, controle e fiscalização, estabelecendo, de forma explícita, a responsabilização pelo seu cumprimento, ou seja, a autoridade marítima mesmo que só esteja observando o fato danoso deverá informar seus superiores a fim de fiscalizar, levantar informações, encaminhar dados e ou comunicar os órgãos reguladores.

Especificamente, o artigo $15^{35}$ da referida lei trata do descarte da água de lastro, remetendo como todas as infrações desta lei, as sanções punitivas previstas na Lei dos Crimes Ambientais ${ }^{36}$.

33 BRASIL. Lei $n^{\circ}$ 9.966, de 28 de abril de 2000. Dispõe sobre a prevenção, o controle e a fiscalização da poluição causada por lançamento de óleo e outras substâncias nocivas ou perigosas em águas sob jurisdição nacional e dá outras providências. Disponível em < http://www.planalto.gov.br/ccivil_03/Leis/L9966.htm>. Acesso em 08 nov. 2015.

34 No Brasil, Lei 9666/2000, in verbis: "Art. 27 São responsáveis pelo cumprimento desta Lei: - a autoridade marítima, por intermédio de suas organizações competentes, com as seguintes atribuições". BRASIL.Lei $n^{\circ}$ 9.966, de 28 de abril de 2000. Dispõe sobre a prevenção, o controle e a fiscalização da poluição causada por lançamento de óleo e outras substâncias nocivas ou perigosas em águas sob jurisdição nacional e dá outras providências. Disponível em <http://www.planalto.gov.br/ccivil_03/leis/L9966.htm>. Acesso em 03 maio 2015.

35 No Brasil, Lei 9666/2000, in verbis: "Art. 15 É proibida a descarga, em águas sob jurisdição nacional, de substâncias nocivas ou perigosas classificadas na categoria "A", definida no art. $4^{\circ}$ desta Lei, inclusive aquelas provisoriamente classificadas como tal, além de água de lastro, resíduos de lavagem de tanques ou outras misturas que contenham tais substâncias. $\S 1^{\circ}$ A água subseqüentemente adicionada ao tanque lavado em quantidade superior a cinco por cento do seu volume total só poderá ser descarregada se atendidas cumulativamente as seguintes condições: I - a situação em que ocorrer o lançamento enquadre-se nos casos permitidos pela Marpol 73/78; II - o navio não se encontre dentro dos limites de área ecologicamente sensível; III - os procedimentos para descarga sejam devidamente aprovados pelo órgão ambiental competente. § $2^{\circ}$ É vedada a descarga de água subseqüentemente adicionada ao tanque lavado em quantidade inferior a cinco por cento do seu volume total". BRASIL. Lei $\mathrm{n}^{\circ} 9.966$, de 28 de abril de 2000. Dispõe sobre a prevenção, o controle e a 
NASCIMENTO. Carlota Bertoli. HAHN, Elaine. Responsabilidade Civil decorrente do dano ambiental causado por dispensação da água de lastro, na costa brasileira. Revista Eletrônica Direito e Política, Programa de Pós-Graduação Stricto Sensu em Ciência Jurídica da UNIVALI, Itajaí, v.11, n.2, 2o quadrimestre de 2016. Disponível em: www.univali.br/direitoepolitica - ISSN 1980-7791.

No que tange a aplicação desta norma é importante esclarecer que será aplicada as regras internacionais e subsidiária a legislação nacional. ${ }^{37}$ Esta situação não exime a aplicação das penalidades aos agentes públicos, uma vez que as regras internacionais atendem aos atores principais dos fatos.

Embora pareça descrito de forma singela e objetiva as responsabilidades dos agentes envolvidos, na prática, encontram-se divergências, inclusive pela manifestação real do agente, havendo peculiaridades em cada situação.

\section{A RESPONSABILIDADE CIVIL}

O instituto da Responsabilidade Civil deve atuar na imputação de sanções cíveis para a compensação de um ato lesivo, fato que vem ocorrendo significativamente na atualidade em relação a dispensação da água de lastro. Deste modo, sua aplicação busca dentro da ciência jurídica a

fiscalização da poluição causada por lançamento de óleo e outras substâncias nocivas ou perigosas em águas sob jurisdição nacional e dá outras providências. Disponível em <http://www.planalto.gov.br/ccivil_03/leis/L9966.htm>. Acesso em 03 nov. 2015.

${ }^{36}$ BRASIL. Lei no 9.605, de 12 de fevereiro de 1998. Dispõe sobre as sanções penais e administrativas derivadas de condutas e atividades lesivas ao meio ambiente, e dá outras providências. Disponível em: http://www.planalto.gov.br/ccivil_03/LEIS/L9605.htm. Acesso em 28 nov. 2015.

37 Art. $2^{\circ}$ Para os efeitos desta Lei são estabelecidas as seguintes definições: I - Marpol 73/78: Convenção Internacional para a Prevenção da Poluição Causada por Navios, concluída em Londres, em 2 de novembro de 1973, alterada pelo Protocolo de 1978, concluído em Londres, em 17 de fevereiro de 1978, e emendas posteriores, ratificadas pelo Brasil; II - CLC/69: Convenção Internacional sobre Responsabilidade Civil em Danos Causados por Poluição por Óleo, de 1969, ratificada pelo Brasil; III - OPRC/90: Convenção Internacional sobre Preparo, Resposta e Cooperação em Caso de Poluição por Óleo, de 1990, ratificada pelo Brasil; BRASIL. Lei no 9.605, de 12 de fevereiro de 1998. Dispõe sobre as sanções penais e administrativas derivadas de condutas e atividades lesivas ao meio ambiente, e dá outras providências. Disponível em: <http://www.planalto.gov.br/ccivil_03/LEIS/L9605.htm>. Acesso em 28 nov. 2015. 
NASCIMENTO. Carlota Bertoli. HAHN, Elaine. Responsabilidade Civil decorrente do dano ambiental causado por dispensação da água de lastro, na costa brasileira. Revista Eletrônica Direito e Política, Programa de Pós-Graduação Stricto Sensu em Ciência Jurídica da UNIVALI, Itajaí, v.11, n.2, 20 quadrimestre de 2016. Disponível em: www.univali.br/direitoepolitica - ISSN 1980-7791.

reparação de um ato ou fato que tenha ocasionado um dano, necessitando o sujeito ativo reestabelecer ao meio ambiente algo que fora lesado ${ }^{38}$.

Assim, a Responsabilidade Civil dilata-se na medida em que a cada momento surgem inúmeras situações que abarcam sua aplicação, além de uma necessidade interpretativa no que se refere às normas diante da "distância existente entre a regra e o momento de sua aplicação"39, especialmente no direito marítimo.

A Revolução Industrial é um marco dentro da responsabilidade, pois além das expressivas mudanças no que tange à quantidade de produção e distribuição dos produtos, também são necessárias novas logísticas de transporte e distribuição. ${ }^{40}$

Por conseguinte, iniciam-se uma série de atividades novas e suas intercorrências acabam sendo dirimidas através do judiciário. Estas novas responsabilidades acabam gerando um momento chamado de "dano em série, dano em massa, dano coletivo, cujo autor, muitas vezes, é anônimo, sem rosto, sem identidade." ${ }^{41}$

No passado os princípios norteadores traziam a culpa para reputar o evento danoso, como ideia principal estabelecida pela redação do atual artigo 186 do Código Civil ${ }^{42}$, deve ainda subsistir "quatro elementos: 1)

38 SCALASSARA, Lecir Maria. Poluição marinha e proteção jurídica internacional, p. 43.

39 ALVAREZ, Alejandro. Interpretação do Direito e Equidade. Porto Alegre: UFRGS, 2015, p. 24.

${ }^{40}$ FABRIZ, Daury Cesar, OBREGON, Marcelo Fernando Quiroga. O Dever Fundamental De Proteção Ambiental No Mar Territorial - Doi: 10.12818/P.03042340.2014v65p17.

Disponível em:<http://www.derechoycambiosocial.com/revista041/o_dever_fundamental_de_pro tec3\%87ao_ambiental.pdf>. Acesso em: 22 nov. 2015.

41 CAVAliere FILHO, Sergio. Programa de Responsabilidade Civil. 11 ed. São Paulo: Atlas, 2014, p. 3.

${ }^{42}$ In verbis: "Aquele que, por ação ou omissão voluntária, negligência ou imprudência, violar direito

e causar dano a outrem, ainda que exclusivamente moral, comete ato ilícito." BRASIL. Lei no 10.406, de 10 de janeiro de 2002. Institui o Código Civil. Diário Oficial da 
NASCIMENTO. Carlota Bertoli. HAHN, Elaine. Responsabilidade Civil decorrente do dano ambiental causado por dispensação da água de lastro, na costa brasileira. Revista Eletrônica Direito e Política, Programa de Pós-Graduação Stricto Sensu em Ciência Jurídica da UNIVALI, Itajaí, v.11, n.2, 2o quadrimestre de 2016. Disponível em: www.univali.br/direitoepolitica - ISSN 1980-7791.

ação ou omissão; 2) dano; 3) nexo causal; 4) culpa ou dolo, para que haja o dever de indenizar." Havendo uma prevalência da teoria de responsabilidade subjetiva para a responsabilização daquele que comete o dano. 43

Assim, com enorme dificuldade para imputação de sanções que abrangem condutas mais complexas, surge através da tutela do direito ambiental, a teoria de responsabilidade objetiva, sendo nesta seara que a teoria do risco $^{44}$ ganha adeptos, e aparece na legislação brasileira inicialmente nas leis especiais. ${ }^{45}$

Tendo em vista que o ordenamento jurídico brasileiro não possui uma regulação especifica quanto à dispensação da água de lastro, tão pouco quanto às espécies da bioinvasão, deve-se ter em conta que o Direito Ambiental, em especial o Marítimo e as Convenções Internacionais, são os reguladores para a imputação das sanções, nas situações de danos ambientais. ${ }^{46}$

União: seção 1, Brasilia, DF. Ano 139, n.8, p.1-74, 11 jan. 2002. Disponível em: http://www.planalto.gov.br/ccivil_03/leis/2002/L10406.htm. Acesso em 10 nov. 2015.

43 BEDRAN, Karina Marcos; MAYER, Elizabeth. A Responsabilidade Civil por danos ambientais no direito brasileiro e comparado. Veredas do Direito, Belo horizonte, $v$. 10, n. 19, p. 45-88, jan./jun.2013. Disponível em: http://www.egov.ufsc.br/portal/sites/default/files/a_responsabilidade_civil_por_danos _ambientais_no_direito_brasileiro_e_comparado.pdf. Acesso em: 20 ago.2015.

44 Assim, para Ulrich Beck, a reflexividade do desenvolvimento capitalista moderno, com a radicalização da modernização (modernidade reflexiva), repercute na transição da sociedade industrial (sociedade de classes sociais) para a sociedade de risco (sociedade de posições de riscos). CARVALHO, Délton Winter de. Dano ambiental futuro: a responsabilidade civil pelo risco ambiental. 2. ed. Porto Alegre: Livraria do Advogado, 2013, p. 33.

45 STEIGLEDER, Annelise Monteiro. Responsabilidade Civil ambiental: as dimensões do dano no direito brasileiro. 2 ed. Porto Alegre: Livraria do Advogado, 2011, p. 57.

46 DAMACENA, Fernanda Dalla Libera; SILVA, Renato Carvalho da. Bioinvasão por água de lastro:um problema de direito e uma ameaça à sustentabilidade. Revista Eletrônica Direito e Política, Programa de Pós-Graduação Stricto Sensu em Ciência Jurídica da UNIVALI, Itajaí, V.10, n.1, edição especial de 2015. Disponível em <www.univali.br/direitoepolitica>. Acesso em 08 nov. 2015. 
NASCIMENTO. Carlota Bertoli. HAHN, Elaine. Responsabilidade Civil decorrente do dano ambiental causado por dispensação da água de lastro, na costa brasileira. Revista Eletrônica Direito e Política, Programa de Pós-Graduação Stricto Sensu em Ciência Jurídica da UNIVALI, Itajaí, v.11, n.2, 20 quadrimestre de 2016. Disponível em: www.univali.br/direitoepolitica - ISSN 1980-7791.

Com a superação dos ciclos e a necessidade do sistema constitucional moderno, ao longo dos tempos se abarcam inúmeros ajustes, sem que haja uma hierarquização axiológica, especialmente no diz respeito à poluição por água de lastro, modificando-se através das incongruências atuais. ${ }^{47}$

Assim, os princípios fundamentais, dentre eles destacam-se os da prevenção e da precaução, são compreendidos como condicionadores das instruções normativas. ${ }^{48}$

A Responsabilidade Civil, suas teorias e os princípios fundamentais do Direito são apontados para dirimir e aplicar a imputação das sanções aqueles que cometem dano ao meio ambiente, em especial na ocorrência à dispensação da água de lastro.

\subsection{DANO AMBIENTAL - PRINCÍPIOS CONSTITUCIONAIS: PRECAUÇÃo E PREVENÇÃo}

Os princípios constituem os pilares norteadores da legislação ambiental. Os princípios da prevenção e precaução são estímulos que servem de guia no sentido da elaboração das normas, além da interpretação e orientação das lacunas nas regras vigentes. ${ }^{49}$

Embora deva-se ter consciência que "tem o Direito do Mar seus próprios princípios, que individualizam como um campo normativo particular." ${ }^{50}$, o Direito Ambiental apresenta dois princípios importantíssimos ao resguardo do Direito no sentido universal, sendo eles o Princípio da Precaução e o Princípio da Prevenção ${ }^{51}$.

47 MENEZES, Wagner. O Direito do Mar, p. 57.

48 FREITAS, Juarez. Sustentabilidade: direito ao futuro, p.296.

49 MENEZES, Wagner. O Direito do Mar, p. 49.

50 MENEZES, Wagner. O Direito do Mar, p. 50.

51 Neste sentido: "Prevenção e precaução constituem termos de noção sinônimas vinculadas sempre as ações preventivas ou acautelatórias no sentido de evitar, 
NASCIMENTO. Carlota Bertoli. HAHN, Elaine. Responsabilidade Civil decorrente do dano ambiental causado por dispensação da água de lastro, na costa brasileira. Revista Eletrônica Direito e Política, Programa de Pós-Graduação Stricto Sensu em Ciência Jurídica da UNIVALI, Itajaí, v.11, n.2, 2o quadrimestre de 2016. Disponível em: www.univali.br/direitoepolitica - ISSN 1980-7791.

O Princípio da Precaução é considerado o mais promissor dentro do direito Ambiental, disciplinando que "emissões de poluição potencialmente poluentes, devem ser reduzidas, mesmo quando não haja prova cientifica evidente do nexo causal entre emissões e os efeitos". ${ }^{52}$

É do possível poluidor o ônus da prova ao justificar que tomou os devidos cuidados a fim de evitar um acidente ambiental, isso porque qualquer decisão a ser tomada deverá direcionar-se obrigatoriamente a favor do meio ambiente. ${ }^{53}$

O Direito Ambiental, de um modo geral, prima pela não realização do dano, como instrumentos preventivos, havendo uma ação inibitória. Assim não pode deixar que a possibilidade de ressarcimento sobrevenha para solucionar o dano, "a degradação, como regra, é irreparável". ${ }^{54}$

impedir ou reduzir o dano ou o perigo efetivo, iminente ou potencial, quer diante da certeza cientifica, quer diante da incerteza cientifica." CUSTÓDIO, Helita Barreira. Responsabilidade Civil por danos ao meio ambiente. São Paulo: Millennium, 2006. P. 716. "Princípio da prevenção: ...nos seus elementos centrais: (a) alta e intensa probabilidade (certeza) de um dano especial ou anômalo; (b) atribuições e possibilidade de o Poder Público evitar o dano social, econômico ou ambiental; e (c) ônus estatal de produzir a prova de excludente do nexo de causalidade intertemporal. Princípio da precaução: ...dotado de eficácia direta e imediata, impõe ao Poder Público diligências não tergiversáveis, com a adoção de medidas antecipatórias e proporcionais, mesmo nos casos de incerteza quanto á produção de danos fundamentalmente temidos (juízo de verossimilhança)." FREITAS, Juarez.

Sustentabilidade: direito ao futuro,p. 285. Principio da Prevenção: "Aplica-se esse princípio, como se disse, quando o perigo é certo e quando se tem elementos seguros para afirmar que uma determinada atividade é efetivamente perigosa. Princípio da Precaução: A invocação do princípio da precaução é uma decisão a ser tomada quando a informação cientifica é insuficiente, inconclusiva e incerta e haja indicações de que possíveis efeitos sobre o ambiente, a saúde das pessoas ou dos animais ou a proteção vegetal possam ser potencialmente perigosos e incompatíveis com o nível d proteção escolhido." MILARÉ, Édis. Direito do ambiente: a gestão ambiental em foco. 7. ed. São Paulo: Revista dos Tribunais, 2011. P. 1070.

52 FREITAS, Juarez. Sustentabilidade: direito ao futuro, p..287.

53 CANOTILHO, José Joaquim Gomes; LEITE, José Rubens Morato. Direito Constitucional Ambiental Brasileiro. 3.ed. São Paulo: Saraiva, 2010, p.62.

54 MILARÉ, Edis. Direito do ambiente: a gestão ambiental em foco,p. 1250. 
NASCIMENTO. Carlota Bertoli. HAHN, Elaine. Responsabilidade Civil decorrente do dano ambiental causado por dispensação da água de lastro, na costa brasileira. Revista Eletrônica Direito e Política, Programa de Pós-Graduação Stricto Sensu em Ciência Jurídica da UNIVALI, Itajaí, v.11, n.2, 20 quadrimestre de 2016. Disponível em: www.univali.br/direitoepolitica - ISSN 1980-7791.

O Princípio da Precaução esta implícito no artigo $225^{55}$ da Constituição Federal de 1988 especialmente quando determina ao Poder Público a exigência de estudos de impacto ambiental e o controle da produção, comercialização ou circulação de produtos ou serviços, interferindo diretamente na livre iniciativa, demonstrando claramente a preocupação do legislador com o direito humano difuso e a influência germânica na sua redação.

Isso porque o seu surgimento deu-se na Alemanha ocidental, aparecendo pela primeira vez, de forma expressa, na Conferência de proteção ao Mar do Norte $^{56}$. O Princípio da Precaução "recomenda a ponderação das preocupações ambientais e cautela diante dos perigos desconhecidos, mas prováveis", ${ }^{57}$ uma busca através das ciências que possam orientar as dimensões de um possível dano.

De outra forma, o Princípio da Prevenção denota a existência de um perigo abstrato que foi reconhecido, "transformando-se em perigo concreto, impondo-se as medidas preventivas para evitar a produção do dano ou a sua repetição. ${ }^{\prime \prime 8}$

55 Art. 225. Todos têm direito ao meio ambiente ecologicamente equilibrado, bem de uso comum do povo e essencial à sadia qualidade de vida, impondo-se ao Poder Público e à coletividade o dever de defendê-lo e preservá-lo para as presentes e futuras gerações. $\mathbf{\$} \mathbf{1}^{\mathbf{0}}$ Para assegurar a efetividade desse direito, incumbe ao Poder Público: (...) IV - exigir, na forma da lei, para instalação de obra ou atividade potencialmente causadora de significativa degradação do meio ambiente, estudo prévio de impacto ambiental, a que se dará publicidade; $\mathbf{V}$ - controlar a produção, a comercialização e o emprego de técnicas, métodos e substâncias que comportem risco para a vida, a qualidade de vida e o meio ambiente; (...). BRASIL. Constituição (1988). Constituição da República Federativa do Brasil. Brasília, DF: Senado Federal, 1988. Disponível em: http://www.planalto.gov.br/ccivil_03/Constituicao/Constituicao.htm>. Acesso em: 24 set. 2015.

56 Para tanto ver: CALIXTO, Robson José. Incidentes Marítimos; 2 ed. São Paulo: Lex Editora, 2006, p. 241.

57 STEIGLEDER, Annelise Monteiro. Responsabilidade Civil ambiental: as dimensões do dano no direito brasileiro, p. 164.

58 STEIGLEDER, Annelise Monteiro. Responsabilidade Civil ambiental: as dimensões do dano no direito brasileiro, p. 165. 
NASCIMENTO. Carlota Bertoli. HAHN, Elaine. Responsabilidade Civil decorrente do dano ambiental causado por dispensação da água de lastro, na costa brasileira. Revista Eletrônica Direito e Política, Programa de Pós-Graduação Stricto Sensu em Ciência Jurídica da UNIVALI, Itajaí, v.11, n.2, 20 quadrimestre de 2016. Disponível em: www.univali.br/direitoepolitica - ISSN 1980-7791.

É importante a consideração e utilização destes princípios, pois as atividades marítimas deixarão danos ambientais não apenas no presente, mas de maneira mais profunda nas gerações futuras. ${ }^{\mathbf{5 9}}$

Atualmente não há um sistema de tratamento da água de lastro completamente seguro, o que torna necessário uma maior observação dos princípios de prevenção e precaução nas atividades marítimas.

\subsection{RESPONSABILIDADE CIVIL - OBJETIVA E SUBJETIVA}

A Responsabilidade Civil, dentro dos conceitos de dano ambiental, busca "designar tanto as alterações nocivas como os efeitos que tal alteração provoca na saúde das pessoas e seus interesses." 60

A responsabilidade subjetiva tem observação na prática de atos ilícitos, uma vez que a ação, ou omissão voluntária, negligência, imprudência ou imperícia, pressupõe a vontade da prática daquele ato, dolo, ou ainda da ação e ou omissão de alguma conduta, ou seja, da culpa, assim o causador do dano teria a obrigação de reparar. ${ }^{61}$

A responsabilidade objetiva, "em vez de se basear numa culpa, se alicerça em um risco." Assim, "existindo relação de causalidade, entre o dano experimentado pela vítima e do ato do agente surge o dever de indenizar". ${ }^{62}$

59 Neste sentido: "o dano ambiental futuro consiste em operacionalização pragmáticosistêmica princípio da equidade intergeracional e dos princípios da precaução e prevenção, avaliando-se não apenas as dimensões temporais do passado ou do presente, mas inserindo na estrutura sistêmica e nos processos de tomada de decisão jurídica condições semânticas para a observação e formação de vínculos com o horizonte futuro. CARVALHO, Délton Winter de. Dano ambiental futuro: a responsabilização civil pelo risco ambiental, p. 190.

60 STEIGLEDER, Annelise Monteiro. Responsabilidade Civil ambiental: as dimensões do dano no direito brasileiro, p. 99.

61 MILARÉ, Edis. Direito do ambiente: a gestão ambiental em foco, p. 1246.

62 CUSTÓDIO, Helita Barreira. Responsabilidade Civil por danos ao meio ambiente. São Paulo: Millennium, 2006, p. 227/238. 
NASCIMENTO. Carlota Bertoli. HAHN, Elaine. Responsabilidade Civil decorrente do dano ambiental causado por dispensação da água de lastro, na costa brasileira. Revista Eletrônica Direito e Política, Programa de Pós-Graduação Stricto Sensu em Ciência Jurídica da UNIVALI, Itajaí, v.11, n.2, 20 quadrimestre de 2016. Disponível em: www.univali.br/direitoepolitica - ISSN 1980-7791.

A Responsabilidade Civil no que tange o dano ambiental será sempre o da teoria objetiva, significa que quem danificar o meio ambiente tem o dever de repará-lo, independente de culpa ou dolo. Esta forma de responsabilidade busca a indenização ou a reparação dos "danos causados ao meio ambiente e aos terceiros afetados por sua atividade". ${ }^{63}$

A grande problemática desta situação está realmente nas causas resultantes do dano ambiental, os quais poderão ser concorrentes, simultâneas ou sucessivas. ${ }^{64}$ Assim, o sistema de Responsabilidade Civil adota a teoria objetiva quando da ocorrência de dano ambiental sob duas vertentes: as que admitem as excludentes de responsabilidade, e as que não admitem. ${ }^{65}$

Neste interim a teoria do risco criado, que admite as excludentes de responsabilidade, ${ }^{66}$ poderá significar, principalmente nesse estudo, a ocorrência da exclusão dos gerenciadores das atividades, aqueles que economicamente são favorecidos com o trabalho do navio e de sua tripulação. ${ }^{67}$

Diferente da teoria do risco integral, que não admite excludentes de responsabilidade, onde o nexo causal abarca ainda mais a situação, pois a simples criação do risco para a vida e ao meio ambiente já é satisfatório

63 MACHADO. Paulo Affonso. Leme. Direito Ambiental Brasileiro. 18. ed. São Paulo: Malheiros, 2010, p. 361.

64 STEIGLEDER, Annelise Monteiro. Responsabilidade Civil ambiental: as dimensões do dano no direito brasileiro, p. 172.

65 BEDRAN, Karina Marcos; MAYER, Elizabeth. A Responsabilidade Civil por danos ambientais no direito brasileiro e comparado. Veredas do Direito, Belo horizonte, $v$. 10, $\mathrm{n}$. 19, P. $45-88, \quad$ jan./jun. 2013.Diponivelem:<http://www.egov.ufsc.br/portal/sites/default/files/a_responsabilid ade_civil_por_danos_ambientais_no_direito_brasileiro_e_comparado.pdf. Acesso em: 20 ago. 2015.

66 Neste sentido: "são excludentes de responsabilidade, que impedem que se concretize o nexo causal, a culpa da vítima, o fato de terceiro, o caso fortuito e a força maior e, no campo contratual, a clausula de não indenizar". VENOSA, Silvio de Salvo. Responsabilidade Civil. 3.ed. São Paulo: Atlas, 2003, p.40.

67 STEIGLEDER, Annelise Monteiro. Responsabilidade Civil ambiental: as dimensões do dano no direito brasileiro, p. 176. 
NASCIMENTO. Carlota Bertoli. HAHN, Elaine. Responsabilidade Civil decorrente do dano ambiental causado por dispensação da água de lastro, na costa brasileira. Revista Eletrônica Direito e Política, Programa de Pós-Graduação Stricto Sensu em Ciência Jurídica da UNIVALI, Itajaí, v.11, n.2, 20 quadrimestre de 2016. Disponível em: www.univali.br/direitoepolitica - ISSN 1980-7791.

para a imputação da responsabilidade pelos danos causados pela atividade. ${ }^{68}$

Na responsabilidade objetiva a discussão não deve se ater no fato de culpa daquele que causou o dano, pois, "a culpa é vinculada ao homem, o risco é ligado ao serviço, a empresa, a coisa, ao aparelhamento"69. Ora, embora o lastreamento ocorra por uma atividade do homem, o mesmo é necessário à economia.

Diante disso, a proteção do meio ambiente marinho deverá ser resguardada, embora a doutrina e a jurisprudência não sejam uniformes quanto as duas vertentes de responsabilidade, não se pode punir injustamente tão pouco deixar de reconhecer a lesão causada.

\section{DisPensaÇÃo da ÁguA de LASTRO e RESPONSABILIDADE CIVIL}

A água de lastro quando dispensada de maneira irregular é considerada uma forma de poluição. Assim, o instituto da Responsabilidade Civil auxilia na atuação punitiva do descumprimento da obrigação.

As responsabilidades do armador, proprietário da embarcação, do comandante do navio, e das pessoas jurídicas envolvidas, no transporte e recebimento da mercadoria transportada, estão configuradas nas suas medidas de ação e ou omissão. Tais responsabilidades muitas vezes são acopladas no âmbito dos contratos de transporte marítimo que possuem suas características e particularidades dentro daqueles serviços. 70

No momento que inicia seu deslocamento comercial o comandante do navio tem responsabilidades, tornando-se este "profissional uma espécie

68 MILARÉ, Edis. Direito do ambiente: a gestão ambiental em foco, p. 1253.

${ }^{69}$ CAVAlIERE FILHO, Sergio. Programa de Responsabilidade Civil. 11 ed. São Paulo: Atlas, 2014, p. 182.

70 MARTINS, Eliane Maria Octaviano. Curso de Direito Marítimo. Barueri: Manole, 2015, p.479. 
NASCIMENTO. Carlota Bertoli. HAHN, Elaine. Responsabilidade Civil decorrente do dano ambiental causado por dispensação da água de lastro, na costa brasileira. Revista Eletrônica Direito e Política, Programa de Pós-Graduação Stricto Sensu em Ciência Jurídica da UNIVALI, Itajaí, v.11, n.2, 20 quadrimestre de 2016. Disponível em: www.univali.br/direitoepolitica - ISSN 1980-7791.

de prefeito, juiz, tabelião e delegado de uma pequena cidade chamada navio." 71

Desta forma deverá "cumprir e fazer cumprir a legislação, as normas e os regulamentos vigentes, bem como os atos e as resoluções internacionais ratificadas pelo Brasil" ${ }^{72}$, assim como determina a Lei $9.537 / 97^{73}$, remetendo à figura do comandante funções de direito púbico e privado.

Ademais, deve-se considerar que as embarcações quando contratadas para transporte de mercadorias possuem contratos específicos, e responsabilidades quanto a sua carga. Importante destacar que pessoas físicas e jurídicas acabam se confundindo, necessário então que haja uma análise profunda. ${ }^{74}$

Os atos do comandante refletem em todo o conjunto comercial. Assim quando por seu comando, propõe o despejo irregular do lastro pode desencadear uma série de circunstâncias, de responsabilidades administrativas, comerciais, náuticas e jurídicas, a si, ao armador, ao afretador, arrendatário, e em alguns casos surge também a figura de outro profissional, o prático. ${ }^{75}$

71 PIMENTA, Matusalém Gonçalves. Responsabilidade Civil do Prático. 1 ed., Rio de Janeiro:

Lumen Juris, 2007, p. 108.

72 PIMENTA, Matusalém Gonçalves. Responsabilidade Civil do Prático, p. 108.

73 BRASIL. Lei 9.537 de 11 de dezembro de 1997. Dispõe sobre a segurança do tráfego aquaviário em águas sob jurisdição nacional e dá outras providências. Disponível em <http://www.planalto.gov.br/ccivil_03/leis/19537.htm>. Acesso em 03 maio 2015.

74 CORDEIRO, Vanessa Kiewel. Os contratos e a Responsabilidade Civil no direito marítimo: estudo sobre as características e particularidades desta espécie contratual. Rio de Janeiro: Lumen Juris, 2014.

75 "O prático ou piloto marítimo, como é conhecido internacionalmente, é um assessor do comandante da embarcação, para auxiliá-lo nas manobras de entrada ou saída dos portos e vias navegáveis, bem como nas manobras de atracação. Desatracação fundeio, estrada e saída de diques etc. [..] abrangendo todos os movimentos efetuados pelas embarcações no interior da zona de praticagem". PIMENTA, Matusalém Gonçalves. Responsabilidade Civil do Prático, p. 57. 
NASCIMENTO. Carlota Bertoli. HAHN, Elaine. Responsabilidade Civil decorrente do dano ambiental causado por dispensação da água de lastro, na costa brasileira. Revista Eletrônica Direito e Política, Programa de Pós-Graduação Stricto Sensu em Ciência Jurídica da UNIVALI, Itajaí, v.11, n.2, 2o quadrimestre de 2016. Disponível em: www.univali.br/direitoepolitica - ISSN 1980-7791.

\section{A Convenção de Bruxelas, da Convenção de Hamburgo e das Regras de} Haia e Protocolo de Visby, "não mantiveram a falta náutica como um dos casos excludentes de responsabilidade ao transportador", mas seu cumprimento de obrigações é diante o transporte e falha da entrega da carga. ${ }^{76}$

A regra maior que deve ser respeitada, na situação do lastro, é Convenção Internacional para Prevenção de Poluição por Navio (MARPOL) no anexo I, que disciplina quanto as normas para a prevenção deste tipo de poluição ${ }^{77}$, é fundamental na compreensão e aplicação das corretas

76 MARTINS, Eliane Maria Octaviano. Curso de Direito Marítimo, p. $460-481$.

77 Regra 15: 8 Nenhuma descarga no mar deverá conter produtos químicos ou outras substâncias em quantidades ou concentrações que sejam perigosas para o meio ambiente marinho, ou produtos químicos ou outras substâncias introduzidas com a finalidade de ocultar as condições da descarga especificada nesta regra. 9 Os resíduos de óleo que não puderem ser descarregados para o mar de acordo com esta regra deverão ser retidos a bordo para uma descarga posterior para instalações de recebimento. Regra 16: Segregação de óleo e água de lastro e transporte de óleo nos tanques de colisão de vante 1 Exceto como disposto no parágrafo 2 desta regra, nos navios entregues depois de 31 de Dezembro de 1979, como definido na Regra 1.28.2, de arqueação bruta igual a 4.000 ou mais, que não petroleiros, e em petroleiros entregues depois de 31 de Dezembro de 1979, como definido na transportada em qualquer tanque de óleo combustível. 2 Quando a necessidade de transportar grandes quantidades de óleo combustível fizer com que seja necessário transportar água de lastro, que não seja lastro limpo, em qualquer tanque de óleo combustível, esta água de lastro deverá ser descarregada para instalações de recebimento, ou no mar, de acordo com a Regra 15 deste Anexo, utilizando o equipamento especificado na Regra 14.2 deste Anexo, e deverá ser feito um lançamento no Livro Registro de Óleo informando isto. $3 \mathrm{Em}$ um navio de arqueação bruta igual a 400 ou mais, para o qual o contrato de construção tenha sido assinado depois de $1^{\circ}$ de Janeiro de 1982 ou, na ausência de um contrato de construção, cuja quilha tenha sido batida ou que esteja num estágio de construção semelhante depois de $1^{\circ}$ de Julho de 1982, não deverá ser transportado óleo num tanque de colisão de vante, nem num tanque localizado por ante-a-vante da antepara de colisão. 4 Todos os navios, que não os sujeitos aos parágrafos 1 e 3 desta regra, deverão cumprir o disposto naqueles parágrafos, na medida do que for razoável e possível.Regra 1.28.2, de arqueação bruta igual a 150 ou mais, nenhuma água de lastro deverá ser transportada em qualquer tanque de óleo combustível. 2 Quando a necessidade de transportar grandes quantidades de óleo combustível fizer com que seja necessário transportar água de lastro, que não seja lastro limpo, em qualquer tanque de óleo combustível, esta água de lastro deverá ser descarregada para instalações de recebimento, ou no mar, de acordo com a Regra 15 deste Anexo, utilizando o equipamento especificado na Regra 14.2 deste Anexo, e deverá ser feito um lançamento no Livro Registro de Óleo informando isto. $3 \mathrm{Em}$ um navio de arqueação bruta igual a 400 ou mais, para o qual o contrato de construção tenha sido assinado 
NASCIMENTO. Carlota Bertoli. HAHN, Elaine. Responsabilidade Civil decorrente do dano ambiental causado por dispensação da água de lastro, na costa brasileira. Revista Eletrônica Direito e Política, Programa de Pós-Graduação Stricto Sensu em Ciência Jurídica da UNIVALI, Itajaí, v.11, n.2, 20 quadrimestre de 2016. Disponível em: www.univali.br/direitoepolitica - ISSN 1980-7791.

penalidades aos agentes causadores de ação ou omissão quando ocorre a dispensação irregular da água de lastro.

Neste caso, o acionamento do deslastre tem discussão no sentido que o comandante é responsável por todos os fatos que ocorra no navio enquanto esteja a seu comando, mas a responsabilidade recai ao armador, mesmo que tenha locado e seja somente o proprietário da embarcação.

Embora a existência de seguro para as ocorrências de o dano ambiental pareça ser uma solução, poderá ser desvantajoso e considerado um incentivo quanto ao não cumprimento das medidas de precaução, e ainda tornar-se uma licença para poluir. ${ }^{78}$

A dispensação da água de lastro é um ato cuja autonomia de lastrear ou não é do comandante do navio, refletindo ao armador, afretador ou arrendatário, seja solidária ou subsidiariamente.

\section{CONSIDERAÇÕES FINAIS}

A atividade marítima, em especial as realizadas por navios e embarcações, produzem riscos em âmbito extremo, em especial a dispensação de água de lastro. Tal atividade é extremamente necessária para a realização dos transportes comerciais marítimos.

depois de $1^{\circ}$ de Janeiro de 1982 ou, na ausência de um contrato de construção, cuja quilha tenha sido batida ou que esteja num estágio de construção semelhante depois de $1^{\circ}$ de Julho de 1982, não deverá ser transportado óleo num tanque de colisão de vante, nem num tanque localizado por ante-a-vante da antepara de colisão. 4 Todos os navios, que não os sujeitos aos parágrafos 1 e 3 desta regra, deverão cumprir o disposto naqueles parágrafos, na medida do que for razoável e possível. BRASIL. Decreto 2.508, de 4 de março de 1998. Promulga a Convenção Internacional para a Prevenção da Poluição Causada por Navios, concluída em Londres, em dois de novembro de 1973, seu Protocolo, concluído em Londres, em 17 de fevereiro de 1978, suas Emendas de 1984 e seus Anexos Opcionais III, IV e V. Disponível em: <http://www.planalto.gov.br/ccivil_03/decreto/D2508.htm>. Acesso em: 15 nov. 2015.

78 FARINHA, Renato. Direito Ambiental. 1 ed., São Paulo: Leme, 2006, p.104. 
NASCIMENTO. Carlota Bertoli. HAHN, Elaine. Responsabilidade Civil decorrente do dano ambiental causado por dispensação da água de lastro, na costa brasileira. Revista Eletrônica Direito e Política, Programa de Pós-Graduação Stricto Sensu em Ciência Jurídica da UNIVALI, Itajaí, v.11, n.2, 20 quadrimestre de 2016. Disponível em: www.univali.br/direitoepolitica - ISSN 1980-7791.

Desta forma, os danos ocasionados pela dispensação da água de lastro, são irreversíveis e tratam de um bem difuso, de direito fundamental a sociedade, e ao mundo. A necessidade da existência do lastro é indiscutível, somente com este material é possível a estabilidade de navio e por consequência do crescimento econômico.

Embora haja na legislação formas para imputação da Responsabilidade Civil, a mesma não contempla de forma objetiva todos os envolvidos direta ou indiretamente nas ações de dispensação da água de lastro, permitindo interpretações subjetivas no entendimento e imputação das responsabilidades.

Não se pode esquecer que o comandante enquanto responsável pela embarcação é também aquele que receberá a imputação devido ao ato ou comanda da dispensação da água de lastro.

Mas observando a atividade de forma complexa é compreensível que o comandante seja a pessoa que menos lucra com a atividade que exerce, sendo assim, na ocorrência de um dano, fica impossível uma necessária reparação, tendo em vista a equidade valorativa do dano em relação aos ganhos e possibilidades do comandante, sendo mais certo que toda a cadeia de responsáveis possa ser alcançada.

Desse modo, ante ao ínfimo valor pecuniário de sua remuneração, quando comparado aos valores de indenização pelos danos causados, acredita-se que outros agentes devem ser conjuntamente responsabilizados.

Diante da literatura analisada até o momento tem-se material teórico que aponta para a imputação de sanções ao armador, aos transportadores, comandante e ao prático.

A Responsabilidade Civil objetiva, em uma das vertentes, permite que em alguns casos seja arguida os excludentes, quais sejam: fato de terceiro ou 
NASCIMENTO. Carlota Bertoli. HAHN, Elaine. Responsabilidade Civil decorrente do dano ambiental causado por dispensação da água de lastro, na costa brasileira. Revista Eletrônica Direito e Política, Programa de Pós-Graduação Stricto Sensu em Ciência Jurídica da UNIVALI, Itajaí, v.11, n.2, 20 quadrimestre de 2016. Disponível em: www.univali.br/direitoepolitica - ISSN 1980-7791.

culpa da vítima, e caso fortuito e força maior. Analisando o nexo causal e havendo a possibilidade, ao ser arguição das excludentes será dispensado da obrigação de indenizar. ${ }^{79}$

Na teoria do risco criado é admitido as excludentes por perceber que há uma ruptura do nexo de causalidade entre resultado e a atividade do agente. Neste contexto a responsabilidade civil na dispensação da água de lastro encontra guarida na teoria do risco integral, uma vez que os danos ocasionados ao meio ambiente são irreversíveis. Neste sentido, "não se perquire a licitude da atividade, já que tão somente a lesividade é suficiente a provocar a tutela jurisdicional" ${ }^{80}$

A doutrina excepciona ainda uma terceira teoria, aplicada em algumas situações, na qual compreende que somente as excludentes de caso fortuito e força maior possam ser arguidas. Admitindo um meio termo na responsabilidade do causador do dano na existência da dispensação da água de lastro.

Neste momento, vislumbrando os riscos que o deslastre irregular pode trazer a população de todo o mundo, além da sua previsível necessidade de realização nas condutas de manobras marítimas, a teoria mais adequada na responsabilização dos agentes causadores do dano ambiental é a teoria do integral.

Essa implicação decorre de forma evidente do bem jurídico lesado, o qual pertence a toda humanidade, a água é bem de todos, das presentes e futuras gerações, os impactos ambientais sobre a mesma como já observado, podem ser irreversíveis ou de reversibilidade economicamente inviável para um ou alguns dos agentes, sendo certo que o comprometimento de todos gera uma proteção maior.

79 STEIGLEDER, Annelise Monteiro. Responsabilidade Civil ambiental: as dimensões do dano no direito brasileiro, p. 176.

${ }^{80}$ MILARÉ, Edis. Direito do ambiente: a gestão ambiental em foco, p. 1254. 
NASCIMENTO. Carlota Bertoli. HAHN, Elaine. Responsabilidade Civil decorrente do dano ambiental causado por dispensação da água de lastro, na costa brasileira. Revista Eletrônica Direito e Política, Programa de Pós-Graduação Stricto Sensu em Ciência Jurídica da UNIVALI, Itajaí, v.11, n.2, 2o quadrimestre de 2016. Disponível em: www.univali.br/direitoepolitica - ISSN 1980-7791.

Neste ínterim, após análise do conteúdo, a responsabilidade civil objetiva, no amparo da teoria do risco integral, que não admite excludentes de responsabilidade a qual devemos nos orientar para aplicar as sanções cabíveis no deslastre irregular, tendo em vista o bem jurídico tutelado ser de interesse de todos, independente da nação onde ocorra.

\section{REFERÊNCIAS DAS FONTES CITADAS}

ALVAREZ, Alejandro. Interpretação do Direito e Equidade. Porto Alegre: UFRGS, 2015.

BAUMAN, Zygmunt. Modernidade Líquida; tradução Plinio Dentzien. Rio de Janeiro: Zahar, 2001.

BEDRAN, Karina Marcos; MAYER, Elizabeth. A Responsabilidade Civil por danos ambientais no direito brasileiro e comparado. Veredas do Direito, Belo horizonte, v. 10, n. 19, p. 45-88, jan./jun.2013. Disponível em: http://www.egov.ufsc.br/portal/sites/default/files/a_responsabilidade_civil _por_danos_ambientais_no_direito_brasileiro_e_comparado.pdf. Acesso em: 20 ago.2015.

BORGHETTI, Nadia Rita boscardin. A integração das águas: Revelando o verdadeiro Aqüífero Guarani. Disponibilidade e uso da água. Disponível em: http://www.aintegracaodaságuas.com.br/sumario/1-disponibilidadee-uso-da-água. Acesso em: 18 abr. 2015.

BRASIL. Agência Nacional de Vigilância Sanitária - Anvisa. Estudo "Brasil - Água de Lastro". Disponível em: < http://www.anvisa.gov.br/divulga/public/paf/água_lastro3.pdf>. Acesso em: 26 de mar. 2015.

Agência Nacional de Vigilância Sanitária - Anvisa. Resolução da Diretoria Colegiada - RDC No 72, DE 29 DE DEZEMBRO DE 2009. Dispõe sobre o Regulamento Técnico que visa à promoção da saúde nos portos de controle sanitário instalados em território nacional, e embarcações que por eles transitem. Disponível em: < http://portal.anvisa.gov.br/wps/wcm/connect/9cc3f800474576208429d43 fbc4c6735/RDC+N\%C2\%BAo+72+DE+29+DE+DEZEMBRO+DE+2009.pdf ?MOD=AJPERES>. Acesso em: 29 nov. 2015 
. Constituição da República Federativa do Brasil (1967). Emenda constitucional no 1, de 17 de outubro de 1969. Edita o novo texto da Constituição Federal de 24 de janeiro de 1967. Disponível em: <http://www.planalto.gov.br/ccivil_03/constituicao/Emendas/Emc_anterio r1988/emc01-69.htm>. Acesso em: 02 maio 2015.

. DECRETO NO 1.530, DE 22 DE JUNHO DE 1995. Declara a entrada em vigor da Convenção das Nações Unidas sobre o Direito do Mar, concluída em Montego Bay, Jamaica, em 10 de dezembro de 1982.

em: <https://saudeglobaldotorg1.files.wordpress.com/2015/07/cnudm.pdf>. Acesso em: 25 nov. 2015.

. Decreto 2.508, de 4 de março de 1998. Promulga a Convenção Internacional para a Prevenção da Poluição Causada por Navios, concluída em Londres, em dois de novembro de 1973, seu Protocolo, concluído em Londres, em 17 de fevereiro de 1978, suas Emendas de 1984 e seus Anexos Opcionais III, IV e V. Disponível em: <http://www.planalto.gov.br/ccivil_03/decreto/D2508.htm>. Acesso em: 15 nov. 2015.

Decreto 2870, de 4 de março de 1998. Promulga a Convenção internacional sobre preparo, resposta e cooperação em caso de poluição por óleo, assinada em Londres, em 30 de novembro de 1990. Disponível

em: <http://www.planalto.gov.br/ccivil_03/decreto/D2870.htm>. Acesso em: 15 maio 2015.

Decreto 79.437, de 28 de março de 1977. Promulga a Convenção internacional sobre Responsabilidade Civil em danos causados por poluição por óleo, 1969. Disponível em: <http://www.planalto.gov.br/ccivil_03/decreto/1970-1979/D79437.htm>. Acesso em: 15 maio 2015

. Lei $8.617 / 93$, de 04 de janeiro 1993. Dispõe sobre o mar territorial, a zona contígua, a zona econômica exclusiva e a plataforma continental brasileiros, e dá outras providências. Disponível em: <http://www.planalto.gov.br/ccivil_03/leis//8617.htm> Acesso em: 15 maio 2015.

. Lei 9.537, de 11 de dezembro de 1997. Dispõe sobre a segurança do tráfego aquaviário em águas sob jurisdição nacional e dá outras providências. Disponível em 
NASCIMENTO. Carlota Bertoli. HAHN, Elaine. Responsabilidade Civil decorrente do dano ambiental causado por dispensação da água de lastro, na costa brasileira. Revista Eletrônica Direito e Política, Programa de Pós-Graduação Stricto Sensu em Ciência Jurídica da UNIVALI, Itajaí, v.11, n.2, 2o quadrimestre de 2016. Disponível em: www.univali.br/direitoepolitica - ISSN 1980-7791.

<http://www.planalto.gov.br/ccivil_03/leis/I9537.htm>. Acesso em 03 maio 2015.

Lei no 9.605, de 12 de fevereiro de 1998. Dispõe sobre as sanções penais e administrativas derivadas de condutas e atividades lesivas ao meio ambiente, e dá outras providências. Disponível em: http://www.planalto.gov.br/ccivil_03/LEIS/L9605.htm. Acesso em 28 nov. 2015.

. Lei 9.966, de 28 de abril de 2000. Dispõe sobre a prevenção, o controle e a fiscalização da poluição causada por lançamento de óleo e outras substâncias nocivas ou perigosas em águas sob jurisdição nacional e dá outras providências. Disponível em:< http://www.planalto.gov.br/CCivil_03/leis/L9966.htm > Acesso em: 15 maio 2015.

BRASIL. Lei no 10.406, de 10 de janeiro de 2002. Institui o Código Civil. Diário Oficial da União: seção 1, Brasilia, DF. Ano 139, n.8, p.1-74, 11 jan. 2002.2 Disponível http://www.planalto.gov.br/ccivil_03/leis/2002/L10406.htm. Acesso em 10 nov. 2015.

. Ministério da Defesa. Comando da Marinha. Diretoria de Portos e Costas. Disponível em: < https://www.dpc.mar.mil.br/normas/normam>. Acesso em: 02 maio 2015.

CALIXTO, Robson José. Incidentes Marítimos. 2 ed. São Paulo: Lex Editora, 2006.

CANOTILHO, José Joaquim Gomes; LEITE, José Rubens Morato. Direito Constitucional Ambiental Brasileiro. 3.ed. São Paulo: Saraiva, 2010.

Carta Internacional de Direitos Humanos. Disponível em: < http://direitoshumanos.gddc.pt/pdf/Ficha_Informativa_2.pdf $>$. Acesso em: 15 nov. 2015.

CARVALHO, Délton Winter de. Dano ambiental futuro: a responsabilidade civil pelo risco ambiental. 2. ed. Porto Alegre: Livraria do Advogado, 2013.

CAVALCANTE FILHO, João Trindade. Teoria Geral dos Direitos Fundamentais. Disponível em:< http://www.stf.jus.br/repositorio/cms/portaltvjustica/portaltvjusticanoticia 
/anexo/joao_trindadade_teoria_geral_dos_direitos_fundamentais.pdf > . Acesso em: 25 nov. 2015.

CAVAliere FILHO, Sergio. Programa de Responsabilidade Civil. 11ed. São Paulo: Atlas, 2014.

CORDEIRO, Vanessa Kiewel. Os contratos e a Responsabilidade Civil no direito marítimo: estudo sobre as características e particularidades desta espécie contratual. Rio de Janeiro: Lumen Juris, 2014.

CUSTÓDIO, Helita Barreira. Responsabilidade Civil por danos ao meio ambiente. São Paulo: Millennium, 2006.

DAMACENA, Fernanda Dalla Libera; SILVA, Renato Carvalho da. Bioinvasão por água de lastro: um problema de direito e uma ameaça à sustentabilidade. Revista Eletrônica Direito e Política, Programa de Pós-Graduação Stricto Sensu em Ciência Jurídica da UNIVALI, Itajaí, v.10, n.1, edição especial de 2015. Disponível em $<$ www.univali.br/direitoepolitica - ISSN 1980-7791>. Acesso em 08 nov. 2015.

DIRETORIA DE PORTOS E COSTAS. Portaria No 111/DPC (NORMAM13), de 16 de dezembro de 2003. Disponível em: <https://www.dpc.mar.mil.br/normas/normam> Acesso em: 15/03/2015.

FABRIZ, Daury Cesar, OBREGON, Marcelo Fernando Quiroga. O Dever Fundamental De Proteção Ambiental No Mar Territorial - Doi: 10.12818/P.0304-2340.2014v65p17. Disponível em:<http://www.derechoycambiosocial.com/revista041/o_dever_fundam ental_de_protec3\%87ao_ambiental.pdf>. Acesso em: 22 nov. 2015.

FARINHA, Renato. Direito Ambiental. 1 ed., São Paulo: Leme, 2006.

FERREIRA, Aurelio Buarque de Holanda. Mini dicionário da língua portuguesa. 7 ed. Ed. Positivo: Curitiba; 2008.

FREITAS, Dario Almeida Passos de. Poluição Marítima. Curitiba: Juruá, 2009.

FREITAS, Juarez. Sustentabilidade: direito ao futuro. 2.ed. Belo Horizonte: Fórum, 2012. 
FREITAS, Vladimir Passos de. A constituição Federal e a Efetividade das Normas Ambientais. 3ed. São Paulo: RT, 2005.

GIBERTONI, Carla Adriana Comitre. Teoria e prática do direito marítimo. Rio de Janeiro: Renovar, 2014.

INTERNATIONAL MARITIME ORGANIZATION. Disponível em: <www.imo.org >. Acesso em 19 abr. 2015.

INTERNATIONAL MARITIME ORGANIZATION. Building Partnerships to Assist Developing Countries to Reduce the Transfer of Harmful Aquatic Organisms in Ships' Ballast Water. The GloBallast Partnerships project 2007-2016. Disponível em: http://globallast.imo.org/. Acesso em: 24 mar. 2015.

LEITE, José Morato. Ferreira, Heline Sivini. Biocombustíveis - fonte de energia sustentável? Considerações jurídicas e técnicas. São Paulo: Saraiva. 2010.

MACHADO. Paulo Affonso. Leme. Direito Ambiental Brasileiro. 18. ed. São Paulo: Malheiros, 2010.

MARTINS, Eliane Maria Octaviano. Curso de Direito Marítimo. Barueri: Manole, 2015.

MENEZES, Wagner. O Direito do Mar. Brasília: Funag, 2015.

MILARÉ, Edis. Direito do ambiente: a gestão ambiental em foco. 7. ed. São Paulo: Revista dos Tribunais, 2011.

MORE, Rodrigo Fernandes. A poluição do meio ambiente marinho e o princípio da precaução. Disponível em: <http://www.sedep.com.br/artigos/a-poluicao-do-meio-ambientemarinho-e-o-principio-da-precaucao/>. Acesso em: 27 nov. 2015.

PAIM, Maria Augusta. O petróleo no mar. Rio de Janeiro: Renovar, 2011. PIMENTA, Matusalém Gonçalves. Processo Marítimo. 2ed. São Paulo: Manole, 2013.

Matusalém Gonçalves. Responsabilidade Civil do Prático. Rio de Janeiro: Lumen Juris, 2007. 
REALE, Miguel. Lições preliminares de direito. São Paulo: Saraiva, 2002.

SARLET, Ingo Wolfgang. LEITE. George Salomão. Direitos Fundamentais e biotecnologia. São Paulo: Método, 2008.

São Paulo. A água de lastro e seus riscos ambientais/ organização Água de Lastro Brasil. São Paulo: Associação Água de Lastro Brasil, 2009. Disponível em: <ftp:ftp.sp.gov.br/ftppesca/água_lastro.pdf>. Acesso em: 16 mar. 2015.

Meio Ambiente: Água de Lastro. Disponível em: <http://www. portodesantos.com.br/acoesCampanhas. php? pagina $=02>$. Acesso em 19 abr. 2015.

SCALASSARA, Lecir Maria. Poluição marinha e proteção jurídica internacional. Curitiba: Juruá, 2008.

SOUSA, Marcos Ticiano Alves de. A bioinvasão de ambientes aquáticos provocada pela água de lastro das embarcações e suas consequências jurídicas. 2014. 83f. Trabalho de Conclusão de Curso (Monografia) - Departamento de Direito, Universidade Federal do Rio Grande do Norte, Natal, 2014.

STEIGLEDER, Annelise Monteiro. Responsabilidade Civil ambiental: as dimensões do dano no direito brasileiro. 2.ed. Porto Alegre: Livraria do Advogado, 2011.

THOMĖ, Romeu. O princípio da vedação de retrocesso socioambiental. Bahia: JusPodivm, 2014.

VENOSA, Silvio de Salvo. Responsabilidade Civil. 3.ed. São Paulo: Atlas, 2003.

Submetido em: Janeiro de 2016.

Aprovado em: Junho de 2016. 